\title{
ANALISIS KEBUTUHAN DAN TANTANGAN PARADIGMA BARU PEMBELAJARAN SEJARAH DI ERA REVOLUSI INDUSTRI 4.0
}

\author{
Wahyu Djoko Sulistyo, Ulfatun Nafiáh \\ Email:Wahyu.djoko.fis@um.ac.id \\ Jurusan Sejarah Universitas Negeri Malang
}

\begin{abstract}
Abstrak
Pembelajaran sejarah di perguruan tinggi sudah semestinya dikemas yang sesuai dengan kebutuhan zaman. Pembelajaran sejarah yang mengkaji tentang masa lalu harus bisa mengambil peran yang sesuai dengan tuntutan pembelajaran di era Revolusi Industri 4.0, dimana dosen harus mampu menyiapkan perangkat pembelajaran yang mampu membuat mahasiswa dapat berfikir kritis melalui literas digital dengan memanfaatkan beberapa platform online malalui LMS, menekankan pada model pembelajaran Blended Learning, menyediakan sumber belajar yang beragam, dan mampu mengembangakan media pembelajaran inovatif sesuai dengan karakteristik materi sejarah yang diajarkan. Analisis kebutuhan pembelajaran sejarah di UM dilakukan dengan melakukan Survey terhadap mahasiswa pendidikan sejarah. Hasilnya menunjukkan bahwa pembelajaran sejarah yang berlangsung selama ini sudah baik dan Dosen sudah memanfaatkan media sebagai penunjang pembelajaran. Namun karakteristik dosen yang beragam dan tuntutan perkembangan pembelajaran sejarah yang semakin maju manuntut perlunya penyesuaian.Tujuan dari penelitian ini adalah untuk melakukan analisis kebutuhan penggunaan media dalam pembelajaran Sejarah di Perguruan Tinggi. Metode yang digunakan dalam penelitian ini adalah metode Analisis Kebutuhan dengan tahapan observasi, sampling, kuisener, wawancara, dan dokumentasi. Adapun sampel penelitian ini adalah mahasiswa Prodi Pendidikan Sejarah UM. Hasilnya adalah 96,3\% responden menyatakan jika penggunaan media film sebagai salah satu media yang paling sesuai dengan era R.4.0.
\end{abstract}

Kata Kunci: Analisis, Kebutuhan, Tantangan, Paradigma baru, Pembelajaran sejarah, revolusi industri 4.0

\section{Pendahuluan}

Pembelajaran sejarah musti cerdas. Artinya adalah pembelajaran sejarah yang mampu menyesuaikan dengan kondisi dan kebutuhan zaman. Selama ini yang kita pahami mengenai pembelajaran sejarah sering disalah artikan baik dalam pelaksanaan dan pemaknaan. Disekolah maupun diperguruan tinggi mengalami problematika yang serupa bahwa "sejarah harus dihafalkan" hal inilah yang merongrong secara perlahan peran dan fungsi yang sebenarnya dari pembelajaran sejarah (Widja,2018). Seharusnya pembelajaran sejarah tidak hanya terfokus pada cara melihat kemampuan kognitif peserta didik, namun bagaimana tujuan pembelajaran dari sisi 
kognitif, afektif dan psikomotorik dapat tercapai dengan melihat hasil pembelajaran secara konkret. Sanaky (2013:215) mengemukakan perkembangan pesat di dunia teknologi informasi khususnya internet, akan mempercepat aliran ilmu pengetahuan yang dapat menembus batasbatas dimensi ruang, birokrasi, kemampanan, dan waktu.

Pembelajaran sejarah sudah seharusnya dilihat secara umum dengan melihat proses terjadinya perubahan secara menyeluruh. Winkel (2009 : 104) menyatakan bahwa hasil belajar adalah perubahan yang mengakibatkan manusia berubah dalam sikap dan tingkah lakunya sehingga dapat menjadi indikator kualitas dan kuantitas siswa. Banyak persoalan yang dihadapi Pembelajaran sejarah saat ini. Persoalan itu mencakup lemahnya penggunaan teori, miskinnya imajinasi, acuan buku teks dan kurikulum yang state oriented, serta kecenderungan untuk tidak memperhatikan fenomena globalisasi berikut latar belakang historisnya(Subakti,2010).

Sejarah yang seharusnya mampu membangun sebuah kerangka kesadaran masa lampau yang terbentuk dari pemahaman terhadap nilai-nilai yang terkandung dalam setiap peristiwa sejarah terbenturkan dengan realitas yang sesungguhnya. Namun juga harus mampu melihat sisi lain yaitu perkembangan teknologi agar pembelajaran sejarah mampu menjawab tantangan sebuah perubahan yang tidak terhindarkan. Sanaky (2013:215) mengemukakan perkembangan pesat di dunia teknologi informasi khususnya internet, akan mempercepat aliran ilmu pengetahuan yang dapat menembus batas-batas dimensi ruang, birokrasi, kemampanan, dan waktu. Pada perkembangannya Purbo (2000) mengemukakan bahwa akan timbul paradigma baru dalam pembelajaran yang dikenal dengan distributed intelligence (distributed knowledge). Pada paradigma ini fungsi dosen, pengajar, lembaga pendidikan akan beralih dari sumber ilmu pengetahuan menjadi mediator dari ilmu pengetahuan. Kondisi ini mengharuskan dosen harus cepat menyesuaikan diri dengan perubahan yang terjadi agar hasil belajar mahasiswa dapat meningkat.

Dosen sejarah dituntut untuk dapat mengemas pembelajaran yang kritis dengan memanfaatkan teknologi yang tepat, menyediakan sumber dan media pembelajaran yang kreatif dan tepat sasaran sesuai dengan kebutuhan dan karakteristik pembelajaran di kelas. Seperti yang dikemukakan oleh McCalman (2000) Sejarah adalah media terbaik yang kita miliki untuk pengajaran arti kebaikan dan kejahatan dalam urusan manusia. Sejarah menyajikan banyak pelajaran berharga yang dapat dijadikan sumber teladan dalam pembentukan karakter anak bangsa (Hamid, 2014, hlm. 179). Paradigma baru yang sekarang dibangun dalam pembelajaran sejarah adalah paradigma kontruktivisme. Sejarah harus membangun pengetahuan secara sadar oleh si pembelajar. Mungkin 473 | Seminar Nasional Sejarah ke 4 Jurusan Pendidikan Sejarah Universitas Negeri Padang 
selama ini kita terlena dengan paradigma konvensional yang sudah lama dan nyaman kita lakukan. Termasuk di dalamnya adalah seperangkat metode pengajaranya harus bergeser dari yang sifatnya konvensional. Barry dan King (2004:61) menguraikan bahwa metode pembelajarn konvensional merupakan metode yang biasa digunakan guru dalam pembelajaran di kelas untuk menyampaikan informasi secara verbal. Metode ini secara lazim diterapkan oleh para pengajar sejarah dengan tuntutan untuk tuntasnya materi ajar dan berdasarkan penilaian kognitif di akhir pembelajaran.

Tak memungkiri bahwa cakupan materi yang dipelajari dalam hal ini adalah kajian mengenai masa lampau. Meskipun lampau dalam cakupan materinya, namun harus maju dan visioner baik dalam system pembelajaranya. Baik dalam model maupun media yang digunakanya. Karena mengingat subjek pembelajaran di Perguruan Tinggi adalah para mahasiswa yang masuk dalam kategori milenial atau diklasifikasikan dalam generasi ' $z$ '” oleh karena itu perlakukan pembelajaran harus berbeda. Sebagai salah satu unsur penyelenggara pendidikanOleh karena itu setiap orang dituntut untuk memiliki kemampuan bergerak cepat, berpikir cepat, "move fast, act fast" dalam mengambil suatu keputusan adalah suatu bentuk untuk mengantisipasi perubahan yang bergerak cepat (Tilaar, 2000: 351).

Pembelajaran sejarah harus berpacu dengan zaman, butuh penyesuaian-penyesuaian terbaru untuk dapat mengikutinya. Alvin Toffler (1995:238) menyarankan dengan menyusun kurikulum yang mengacu pada masa depan, yang disebutnya "super-industrial Education System". Suatu system kurikulum yang disusun dengan segenap perangkat untuk dapat memenuhi tuntutan perkembangan industry.Teknologi menjadi bagian yang tidak terpisahkan dari kehidupan manusia. Revolusi industry 4.0 menempatkan manusia sebagai salah satu instrument pengguna utama dari produk-produk tehnologi dalam kehidupanya. Perkembangan teknologi yang menjadi ciri khas utama dari zaman ini ini adalah pemanfaatan tehnologi yang berbasiskan jaringan internet. Atau tehnologi tepat guna dalam menunjang terbukanya berbagai akses informasi dan kemudahan dalam berbagai pemenuhan kebutuhan. Pembalajaran sejarah sudah seharusnya mampu untuk dapat menyesuaikan diri dengan hal tersebut. Pemanfaatan IT menjadi syarat mutlak untuk dapat menciptakan iklim pembelajaran yang sesuai dengan kebutuhan jaman.Melalui artikel ini, penulis akan membahas secara lebih mendalam bagaimana pembelajaran sejarah di Jurusan Sejarah Universitas Negeri Malang secara lebih konkret dengan melihat kebutuhan dan tantangan pembelajaran sejarah di Era Revolusi Industri 4.0. 


\section{Metode Penelitian}

Metode yang digunakan dalam penelitian ini adalah metode analisis kebutuhan yang termasuk ke dalam penelitian Pra Pengembangan pada prosedur penelitian pengembangan R \& D (Sugiyono: 2010) . Penelitian ini hanya terbatas pada analisis kebutuhan Pembelajaran sejarah di Era Revolusi Industri 4.0 bagi mahasiswa Jurusan Sejarah UM yang bersumber dari hasil observasi awal yang dilakukan pada minggu pertama bulan April 2019, sampling, wawancara dengan dosen dan mahasiswa Jurusan Sejarah, kuisener dan dokumentasi. Teknik pengumpulan data dalam penelitian ini menggunakan instrumen Angket analisis kebutuhan untuk mahasiswa Sejarah UM. Agar peneliti memiliki gambaran konkret tentang kebutuhan pembelajaran sejarah di Perguruan Tinggi maka peneliti melakukan observasi di 4 kelas yaitu dua kelas di Semester II dan dua kelas di semester IV. Keempat kelas tersebut memiliki karakteristik yang berbeda, sehingga gambaran kebutuhan akan lebih konkret. Adapun Subjek dalam penelitian ini adalah mahasiswa Program Studi Pendidikan Seajarah, Fakultas Ilmu Sosial Universitas Negeri Malang. Analisis kuantitatif. “quantitative research is an approach for testing objective theories by examining the relationship among variables. These variables, in turn, can be measured, typically on instruments, so that numbered data can be analyzed using statistical procedures(Creswell, 2014:32).Jumlah sampel yang digunakan adalah sejumlah 188 mahasiswa sebagai responden,yaitu mahasiswa semester 2 atau generasi termuda di Jurusan Sejarah. Instrument pengambilan data menggunakan angket dengan teknik pengumpulan data melalui google form yang diinformasikan kepada mahasiswa untuk diisi. Analisis yang dilakukan dengan membuat besaran prosentase dengan menganalisa factor-faktor pilihan sesuai dengan alas an yang dituliskan oleh responden saat mengisi angket. Dari prosentase jumlah responden dalam setiap indicator sehingga dapat ditarik kesimpulan hasil survey yang dilakukan.

\section{Hasil dan Pembahasan}

Revolusi industri menempatkan Dosen sebagai fasilitator yang harus memiliki kemampuan kreatif dalam membangun pengetahuan bagi mahasiswa. Proses belajar sejarah harus lebih mementingkan proses bukan sekedar hasil belajar yang tertuang dalam nilai akhir pada setiap proses pembelajaran. Tuntutan perkembangan teknologi harus secara sigap mampu 
ditangkap dengan baik melalui kesiapan dosen dalam merancang pebelajaran yang kritis, keratif dan inovatif.

Hasil penelitian ini dilakukan untuk mengetahui respon Mahasiswa Sejarah dalam menilai bagaimana pelaksanaan pembelajaran sejarah yang terjadi di perguruan Tinggi, dilakukan survey dengan sample mahasiswa pendidikan Sejarah Universitas Negeri Malang. Survey tersebut untuk melihat bagaimana pembelajaran sejarah yang sudah berlangsung selama ini berdasarkan pengalaman mereka dan untuk melihat seperti apa pembelajaran sejarah yang mereka inginkan sesuai dengan selera zaman yang mereka wakili. Pada lembar kuisioner yang diisi oleh mahasiswa terdapat 10 item soal yang menunjukkan indicator yang hendak diketahui respon dari mahasiswa.

Berikut disajikan Hasil Survey yang dilakukan oleh peneliti pada 8 April 2019 terhadap 188 Mahasiswa Sejarah:

\section{Penilaian Terhadap Pembelajaran Sejarah yang Telah Berlangsung}

Tabel 1. Rekapitulasi Penilaian terhadap Pembelajaran Sejarah

\begin{tabular}{|c|c|c|c|c|}
\hline Indikator & \multicolumn{4}{|c|}{ Jumlah (Prosentase) } \\
\hline Kriteria & Sangat Baik & Baik & Kurang Baik & $\begin{array}{l}\text { Tidak } \\
\text { Baik }\end{array}$ \\
\hline $\begin{array}{l}\text { Berlangsungnya Pembelajaran } \\
\text { Sejarah }\end{array}$ & $31(16,5 \%)$ & $156(83 \%)$ & $1(0,5 \%)$ & $0 \%$ \\
\hline $\begin{array}{lcc}\text { Dosen Sejarah } & \text { dalam } \\
\text { mengajarkan sejarah } & \\
\end{array}$ & $59(31,4 \%)$ & $125(66,5 \%)$ & $4(2,1 \%)$ & $0 \%$ \\
\hline Kriteria & $\begin{array}{l}\text { Sangat } \\
\text { Sering } \\
\end{array}$ & Sering & Jarang & $\begin{array}{l}\text { Tidak } \\
\text { Pernah }\end{array}$ \\
\hline $\begin{array}{l}\text { Penggunaan Media dalam } \\
\text { pembelajaran sejarah }\end{array}$ & $46(24,5 \%)$ & $101(53,7 \%)$ & $40(21,3 \%)$ & $1(0,5 \%)$ \\
\hline Kriteria & $P P T$ & Gambar & Video Pendek & $\begin{array}{l}\text { Film } \\
\text { Sejarah }\end{array}$ \\
\hline $\begin{array}{l}\text { Media yang sering digunakan } \\
\text { oleh Dosen }\end{array}$ & $172(91,5 \%)$ & $1(0,5 \%)$ & $3(1,6 \%)$ & $12(6,4 \%)$ \\
\hline
\end{tabular}

\section{Sumber : Data Peneliti (2019)}

Pada indikator pertama pada tabel untuk menilai bagaimana pembelajaran sejarah yang sudah berlangsung selama ini. Sejumlah 83,\% menyatakan sudah berlangsung baik dan 16,5\% menyatakan baik sekali. Berarti terdapat $0,5 \%$ yang masih menyatakan bahwa pembelajaran sejarah yang sudah mereka alami kurang atau tidak baik. Alasan mereka menilai baik dan sangat 
baik berhubungan dengan keberhasilan mereka secara kognitif mampu menuntaskan pembelajaran sejarah tersebut pada satu mata kuliah yang sudah mereka tempuh. Sedangkan yang merasa masih kurang baik dikarenakan capaian yang mereka peroleh kurang sesuai dengan harapanya.Dilihat dari hasil ini maka dapat ditarik kesimpulan aspek kognitif masih mandominasi dalam standar penilaian mahasiswa terhadap keberhasilan pembelajaran sejarah.

Keberhasilan pembelajaran didukung dengan keberhasilan Dosen dalam melangsungkan pembelajaran. Dilihat pada indikator apakah Dosen mengajarkan sejarah dengan baik maka sejumlah 66,5 \% menyatakan berlangsung baik dan 31,4\% menyatakan sangat baik. Penilain ini mereka berikan berdasarkan beberapa indikator salah satunya dalah kesesuaian antara keahlian Dosen dengan mata kuliah yang diampu dan keterampilan dalam mengelola kelas serta penugasan yang tidak memberatkan. Secara administratif dosen mengajar sesuai ketentuan yang dstandarkan bahwa kegiatan belajar harus dilaksanakan minimal 12 kali pertemuan. Terdapat 2,1\% mahasiswa yang menilai jika dosen menyelenggarakan pembelajaran kurang baik lebih ditekankan pada tidak terpenuhinya standar minimal pertemuan tatap muka antara Dosen dengan Mahasiswa baik secara online maupun offline.

Indikator selanjutnya mengenai penggunaan media oleh Dosen dalam mengajarkan Sejarah. Mengingat media merupakan komponen penting selain pengajar itu sendiri dalam pembelajaran sejarah. Karena peran media sebagai pendukung utama dalam pembelajaran yang lebih efektif. Kemp \&Dayton dalam Daryanto (2010: 6) menyatakan bahwa media pembelajaran adalah segala sesuatu yang dapat digunakan untuk menyalurkan pesan (bahan pembelajaran), sehingga dapat merangsang perhatian, minat, pikiran, dan perasaan siswa dalam kegiatan belajar untuk mencapai tujuan belajar. Selain itu, media pembelajaran sejarah membuat sejarah nyata, jelas, vital dan menarik (Kochhar, 2008: 210).

Hasil survey menunjukkan bahwa 24,5 \% sangat sering dan 53,7\% menyatakan sering, Dosen dalam mengajar Sejarah menggunakan media. Namun terdapat 21,3\% bersifat kadangkadang. Dari data di atas nampak sekali bahwa Dosen dominan menggunakan media untuk menyampaikan materi dalam pembelajaranya. Hanya saja media yang mereka gunakan berfariatif mulai dari media Power Point Teks (PPT), video pendek dan Film. Dari media yang digunakan oleh Dosen dominasi PPT sangat mutlak yaitu 91,5\% dan hampir seluruh dosen menggunakan media PPT dalam penyampaian materinya. Meskipun dipandang cukup kurang 
relevan untuk menyajikan materi di era sekarang namun peranya masih menempati posisi utama karena yang paling praktis dan mudah menyusunya sehingga mayoritas Dosen masih menggunakan perangkat tersebut. Penggunaan media PPT yang mayoritas digunakan oleh dosen memiliki banyak kekurangan salah satunya adalah kurangnya kemampuan menampilkan sajian visual yang lebih hidup lagi. Gambar dan grafik visual yang disajikan tidak bergerak sehingga daya tariknya tidak sekuat dengan televise atau film (Azhar Arsyad, 2006).

\section{Kebutuhan Terhadap Pembelajaran Sejarah yang Diinginkan}

Tabel. 2. Hasil Rekapitulasi Analisis Kebutuhan

\begin{tabular}{|c|c|c|c|c|}
\hline Indikator & \multicolumn{4}{|c|}{ Jumlah (Prosentase) } \\
\hline Kriteria & $\begin{array}{l}\text { Berbasis } \\
\text { Ceramah }\end{array}$ & $\begin{array}{l}\text { Berbasis } \\
\text { Media }\end{array}$ & \multicolumn{2}{|c|}{$\begin{array}{c}\text { Kolaborasi Media dan } \\
\text { Ceramah }\end{array}$} \\
\hline $\begin{array}{l}\text { Konsep pembelajaran } \\
\text { sejarah yang diinginkan }\end{array}$ & $7(3,7 \%)$ & $20(10,6 \%)$ & \multicolumn{2}{|c|}{$161(85,6 \%)$} \\
\hline Kriteria & $\begin{array}{l}\text { Sangat } \\
\text { Setuju }\end{array}$ & Setuju & Kurang Setuju & $\begin{array}{l}\text { Tidak } \\
\text { Setuju }\end{array}$ \\
\hline $\begin{array}{l}\text { Materi Sejarah dikemas } \\
\text { dengan Media }\end{array}$ & $74(39,4 \%)$ & $108(57,4)$ & $6(3,2 \%)$ & $0 \%$ \\
\hline Kriteria & Audio & Visual & \multicolumn{2}{|c|}{ Audio Visual } \\
\hline $\begin{array}{l}\text { Konsep Media yang paling } \\
\text { yang diinginkan }\end{array}$ & $3(1,6 \%)$ & $8(4,3 \%)$ & \multicolumn{2}{|c|}{$177(94,1 \%)$} \\
\hline Kriteria & $P P T$ & Gambar & Video & Film \\
\hline $\begin{array}{l}\text { Bentuk media yang paling } \\
\text { relevan }\end{array}$ & $6(3 \%)$ & $9(5 \%)$ & $34(17 \%)$ & $139(74 \%)$ \\
\hline Kriteria & $\begin{array}{l}\text { Sangat } \\
\text { Sesuai }\end{array}$ & sesuai & $\begin{array}{l}\text { Kurang } \\
\text { Sesuai }\end{array}$ & $\begin{array}{l}\text { Tidak } \\
\text { Sesuai }\end{array}$ \\
\hline $\begin{array}{l}\text { Media Film sejarah dengan } \\
\text { era R. } 4.0\end{array}$ & $79(42 \%)$ & $102(54,3)$ & $7(3,7 \%)$ & $0 \%$ \\
\hline
\end{tabular}

Sumber : Data Peneliti (2019)

Dari sajian data di atas menunjukkan bahwa mahasiswa mendukung untuk dikemasnya materi sejarah kedalam sebuah media pembelajaran. 39,4\% menyatakan sangat setuju dan 57,4 menyatakan setuju, hanya 3,2\% yang menyatakan kurang setuju. Mereka mendukung bahwa pemanfaatan media yang pada survei kondisi pembelajaran di tabel.1, mayoritas dosen menggunakan media pembelajaran, dapat tetap dipertahankan namun perlu adanya inovasi dan pengembangan. Mahasiswa kurang setuju dengan asumsi bahwa materi yang dipahamiakan terbatas jika media yang digunakan oleh dosen masih sama tanpa ada perubahan. Meskipun mayoritas mahasiswa memilih setuju, namun mereka tetap menginginkan peran dosen secara 
proporsional, artinya tidak hanya tergantung dengan media. Harus ada kolaborasi antara penggunaan media dengan metode yang sesuai, hal ini dikemukakan 85,6\% mahasiswa bahwa metode ceramah penting. Karena menurut mahasiswa, kemampuan dosen sejarah menjelaskan materi secara verbal masih sangat dibutuhkan untuk memberi penguatan pemahaman materi yang disampaikan, minimal dalam tahapan apersepsi di awal dan konfirmasi di akhir pembelajaran.

Untuk proyeksi pembelajaran sejarah bagi mahasiswa di zaman sekarang membutuhkan sajian materi yang lebih komunikatif dengan melibatkan semua indera secara optimal . Karena pengoptimalan semua indera dalam belajar mampu membangkitkan kualitas belajar. Melalui potensi indra peserta didik dapat diakomodasi sehingga kadar belajar akan meningkat (Rusman, dkk, 2012: 295). Media pembelajaran yang menunjang untuk hal tersebut adalah media audio visual. Sesuai dengan hasil survey yang dipilih mahasiswa menunjukkan angka 94,1\% memilih media yang berbasiskan audio visual dalam pembelajaran sejarah masa kini dan kedepanya. Konsep media berbasiskan audiovisual mampu untuk mengoptimalkan proses pembelajaran.(Derek McKiernan,1988) Alasan mereka memilih kategori tersebut karena mereka menginginkan suatu kemasan baru dalam media pembelajaran sejarah. Kemajuan zaman dan maraknya berbagai perangkat untuk menghasilkan produk media audio-visual secara murah mendorong mereka untuk menginginkan sajian media sejarah yang lebih menarik.

Bentuk dari media yang dipilih mahasiswa berupa video dan film sejarah. Survey menunjukkan bahwa $74 \%$ memilih bentuk media film sejarah 17\% berupa video. Dominasi ini mendukung untuk penggunaan media audiovisual yang menurut mereka akan lebih memudahkan materi yang disajikan lebih mudah dipahami. Namun masih terdapat beberapa mahasiswa yang menyatakan kurang setuju karena mereka berasumsi bahwa film sejarah terlalu sulit untuk diterapkan dan beberapa diantara mereka menilai ada kesulitan dalam memahami sebuah narasi dalam sajian film dan video yang ditunjukkan dengan mencapai $5 \%$ yang menginginkan media gambar dan $3 \%$ tetap dalam bentuk PPT seperti biasanya.

\section{Diagram 1. Kesesuaian Media Film sebagai Media Pembelajaran Sejarah Era Revolusi Insustri 4.0}




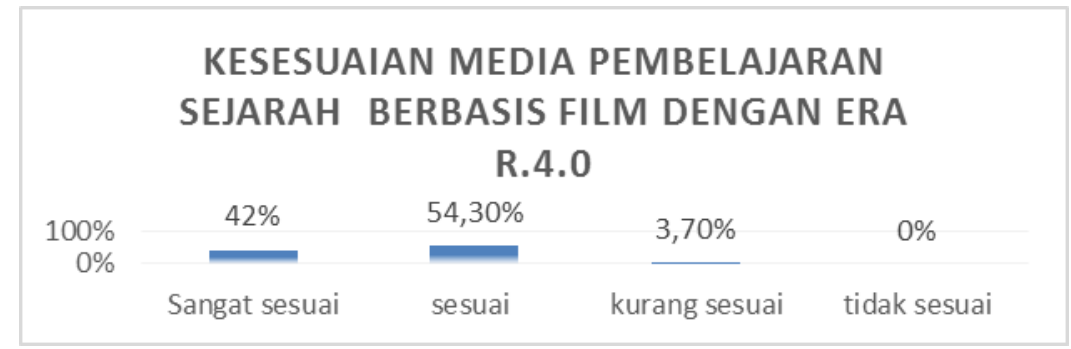

Sumber : Data Peneliti (2019)

Penyajian media pembelajaran sejarah melalui film sejarah sangat sesuai dengan kebutuhan dan selera zaman peserta didik era kini. Terlebih para mahasiswa, berdasarkan penilaian kesesuaian yang mereka pilih menunjukkan angka cukup mutlak yaitu 96,2 \% yang terdiri dari $42 \%$ sangat sesuai dan 54,5 \% menyatakan sesuai. Bagi mereka belajar dengan kemasan menonton dan menganalisa sebuah sajian film akan lebih menarik dan menantang untuk mereka lakukan dari pada hanya mendengar penjelasan dosen baik mealaui media PPT atau hanya secara verbal. 3,8\% menyatakan kurang sesuai dengan alas an bahwa tidak semua materi sejarah dapat dan mampu dikemas dalam sebuah film narasi.

Menurut hasil penelitian dari Husmiati (2010) media film ini mampu membuat perkuliahan menjadi bervariasi, menyenangkan, mudah dipahami, mampu merangsang imajinasi, mengkongkritkan peristiwa yang sebelumnya abstrak dalam waktu singkat dan dapat membawa mahasiswa menembus ruang dan waktu secara tidak langsung karena media film sesuai dengan materi, kebutuhan dan tujuan perkuliahan. Penggunaan Film dalam sebuah pembelajaran bukanlah hal yang baru, memngingat diluar negeri, banyak dieksperimenkan dan menunai hasil yang cukup signifikan untuk film dapat membantu dalam mencapai tujuan pembelajaran (John Sundquid(2010), Masson(2007), Andrew(2009)). Film sejarah dapat menjadi salah satu alternative sumber belajar yang sangat relevan (Deshpande,(2004), Schultz(2014), Compton(2011)).

\section{Permasalahan Utama Mahasiswa Sejarah di Era Revolusi Industri 4.0}

Permasalahan mendasar yang selalu menjadi tantangan bagi mahasiswa di era Revolusi Industri 4.0 adalah budaya literasi yang dimiliki. Berdasarkan data Perpustakaan Nasional tahun 2017, frekuensi membaca orang Indonesia rata-rata hanya tiga sampai empat kali per minggu. Sementara jumlah buku yang dibaca rata-rata hanya lima hingga sembilan buku per tahun (CNN Indonesia). Berdasarkan survey yang dilakukan pada mahasiswa sejarah mengenai permasalahan 
apa saja yang menurut para mahasiswa sejarah paling krusial adalah rendahnya budaya baca yang mereka miliki. Adapun diagram intensitas membaca mahasiswa secara terpisah dapat ditampilkan dalam diagram lingkaran di bawah ini :

\section{Gambar 2. Diagram Intensitas Membaca Mahasiswa}

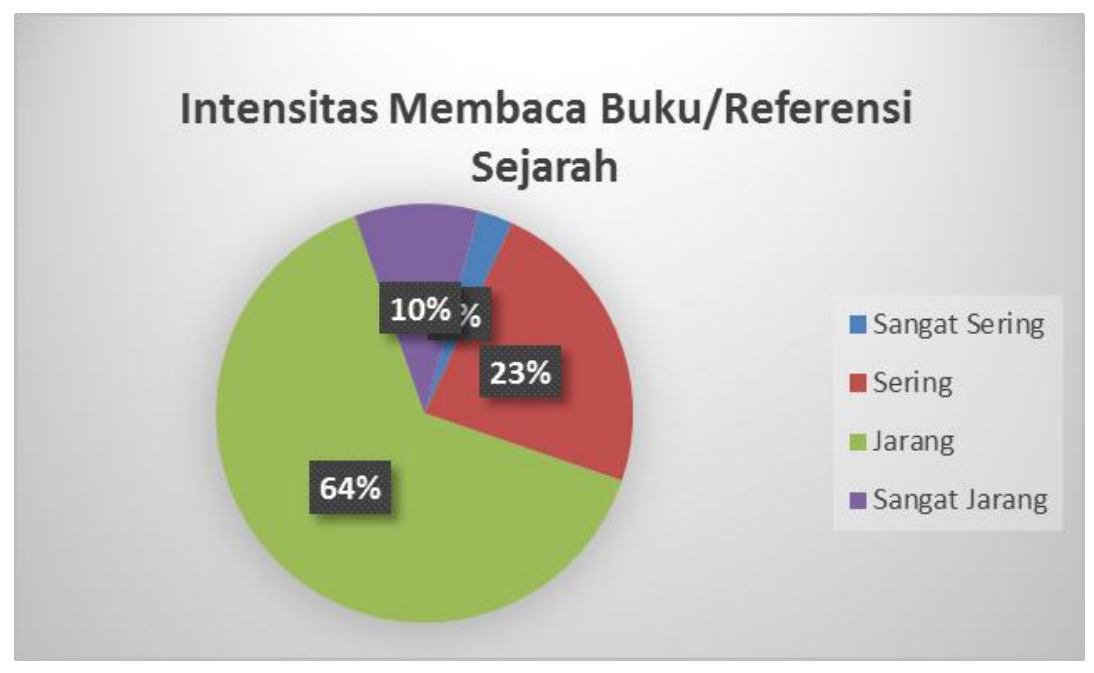

Sumber :Data Peneliti (2019)

Berdasarkan data di atas dapat dilihat problematika rendahnya budaya baca masih tetap sama. Permasalahan utama yang dihadapi oleh mahasiswa pendidikan sejarah adalah tingkat intensitas membaca mereka. Padahal hal ini bukan rahasia umum bahwa budaya baca masyarakat Indonesia cukup rendah. Dari (detik.com,2016) data literasi anak Indonesia berdasarkan pada hasil penelitian Program for International Student Assessment (PISA) rilisan Organisation for Economic Co-Operation and Develompent (OECD) tahun 2015. Indonesia menempati peringkat 62 dari 70 negara yang disurvey. Danyang kedua, peringkat literasi bertajuk 'World's Most Literate Nations' yang diumumkan pada Maret 2016, produk dari Central Connecticut State University (CCSU) menempatkan Indonesia berada pada posisi 60 dari 61 negara yang di survey. Dari data diatas menunjukan bahwa budaya baca masyarakat Indonesia masih cukup rendah. 
Nampak dalam hasil survey yang dilakukan trerhadap mahasiswa sejarah menunjukkan angka 64,\% menyatakan jarang rendah dan $10 \%$ sangat jarang.

Jika dilihat maka hanya ada $26 \%$ mahasiswa yang menyatakan sering dan sangat sering membaca buku sejarah. Salah satu penyebab dari rendahnya budaya baca yang di alami mahasiswa adalah asusmsi terhadap mudahnya akses internet dan sumber rujukan. Sehingga mereka hanya mengambil bagian-bagian terpenting dari yang mereka butuhkan. Selain itu orientasi mereka terhadap informasi praktis pada satu capaian matakuliah menyebabkan mereka jarang membaca. Sedangkan dari sekian prosentase mereka yang mempunyai budaya baca tinggi karena mereka mempunyai alasan yang mendasar mengenai pentingnya kesadaran untuk membaca. Kesadaran baca mereka berkaitan dengan keingintahuan mereka terhadap informasi yang menunjang mengenai materi kuliah atau pengetahuan umum yang relevan. Sumber bacaan mereka baik berasal dari buku-buku koleksi pribadi atau yang disediakan oleh perpustakaan maupun yang berasal dari buku elektronik yang sekarang sudah cukup popular. Mayoritas dari mahasiswa menginginkan untuk literasi elektronik yang berbasiskan system seluler yang mereka miliki yaitu gadged yang secara praktis dan efektif dapat mereka gunakan.Perangkat seluler berpotensi menjadikatalis penting dalam proses ini, karena memungkinkan untuk individual pendekatan, alat, dan informasi yang digunakan dalam proses mendorong pemikiran historis (Alexander,2014). Karena bagi kebutuhan zaman sekarang android sebagai system seluler menjadi hal yang tidak dapat dipisahkan dari hidup manusia. Sehingga dengan dikemasnya referensi-referensi ke dalam ponsel mahasiswa dapat memacu meningkatnya budaya mereka.

\section{Menjawab Tantangan Pembelajaran Sejarah di Era Revolusi Industri 4.0}

Adanya analisis kebutuhan permasalahan yang ada sudah seharusnya ditindaklanjuti dengan upaya perbaikan pembelajaran sejarah di Perguruan Tinggi. Tuntutan perkembangan era Revolusi Industri 4.0 bagi pembelajaran sejarah harus mampu diimbangi dengan menyiapkan mahasiswa agar mampu bertahan dan beradaptasi dengan berbagai perubahan. Perubahan yang dilakukan dapat dimulai dengan penataan kurikulum di Universitas Negeri Malang khususnya Jurusan Sejarah FIS UM yang dilakukan pada tanggal 10 November 2017 dengan pendekatan Kurikulum Berbasis Kehidupan. Kurikulum Jurusan Sejarah yang disajikan sudah mengakomodir kebutuhan pembelajaran sejarah dengan ketentuan KKNI dan pengembangan kapabilitas belajar berbasis kehidupan. Kurikulum pendidikan sejarah juga mempertimbangkan 
dinamika perkembangan IPTEKs dengan cara mengadopsi penggunaan IPTEKs dalam perkuliahan (Katalog Jurusan Sejarah, 2018:2).

Kurikulum Berbasis Kapabilitas di Universitas Negeri Malang dikembangkan dengan prinsip sebagai berikut:1) Berorientasi pada kebutuhan atau peminatan mahasiswa; 2) Menciptakan kemandirian dalam menentukan kecakapan yang akan dimiliki.; 3) Menciptakan kemampuan belajar untuk memperoleh dan memanfaatkan pengetahuan dalam kehidupan. 4) Mengembangkan kemampuan adaptabilitas dan agilitas terhadap perubahan ilmu pengetahuan dan teknologi, sosial ekonomi masyarakat, serta selalu siap belajar mengembangkan keahliannya; 5) Mengembangkan kemampuan memecahkan berbagai situasi dan permasalahan baru yang terjadi di masyarakat dengan cara kreatif dan efisien (Panduan Pengembangan Kurikulum Universitas Negeri Malang, 2018:17).

Melalui pembelajaran sejarah berbasis kapabilitas, maka dosen sejarah dituntut untuk dapat mengembangkan proses pembelajaran yang berstandar. Penetapan standar rancangan perkuliahan dimaksudkan untuk memberikan kontrol mutu minimal terhadap desain perkuliahan pada setiap matakuliah. Komponen Rancangan Perkuliahan minimal berisi tentang Rancangan Perkuliahan Semester (RPS) dan Satuan Acara Perkuliahan (SAP). Secara konkret RPS/SAP yang dikembangkan harus dilengkapi dengan Metode pembelajaran yang mengarah pada pembelajaran kritis. Alternatif yang dapat dikembangkan dengan menggunakan pendekatan student centerdengan model pembelajaran Proyek Based Learning (PjBL) dan Problem Based Learning $(P B L)$.

Agar tujuan pembelajaran dapat tercapai, maka Sumber Daya Manusia yaitu dosen harus mampu mengembangkan perangkat pembelajaran yang inovatif yaitu berupa sumber belajar, media pembelajaran dan perangkat penilaian yang konkret pada setiap pertemuan. Jika semua perangkat telah dikembangkan maka dosen dapat mengembangkan model pembelajaran Blended Learning (cari bahan tentang blended Learning). Konsep Blended Larning dapat diwujudkan dosen dengan pemanfaatan Sistem Pengelolaan Pembelajaran (SIPEJAR) Universitas Negeri Malang. Melalui SIPEJAR UM dosen dapat mengembangkan pembelajaran Sinkronus maya dan Asinkronus Maya sesuai dengan pengalaman pembelajaran yang akan di capai.

Pedoman Pendidikan UM tahun 2016 memperbolehkan pembelajaran daring dan pembelajaran tatap muka, melalui pembelajaran yang beragam inilah, dosen sudah seharusnya 
mampu menggunakan peluang dan mempersiapkan sumber belajar yang konkret dan tahapan pembelajaran yang jelas pada setiap pertemuan. Literasi digital dapat menjadi alternatif muudahkan mahasiswa dalam belajar, dosen dapat menggunggah alamat web seperti: KITLV, NIOD.ID, Portal Garuda untuk mendapatkan sumber sejarah yang sesuai dengan kebutuhan mahasiswa. Hal ini dapat meminimalisir pemanfaatan internet yang tidak sesuai dengan tujuan.

Penggunaan berbagai media pembelajaran seharusnya tidak hanya dapat memanfaatkan namun juga dosen sejarah dituntut dapat mengembangkan sendiri sesuai dengan karakteristik kebutuhan mahasiswa pada setiap kelas dengan pertimbangan karakteristik matakuliah. Mengenai pemanfaatan media pembelajaran, dosen harus mampu mengembangkan pembelajaran yang menarik dengan melibatkan pengetahuan mahasiswa dalam memperoleh pengetahuan. Beberapa dosen telah mampu membuat pengembangan media pembelajaran berbasis IT misalnya Film Dokumenter, Pengembangan media pembelajaran Berbasis Prezi, Augmented Reality, Video Interaktif, dan perangkat bahan ajar dengan menggunakan e-Modul, E-handout dengan flip book, dan bahan ajar Lembar Kegiatan Mahasiswa seuai dengan kebutuhan perkuliahan. Perubahan paradigma baru dalam pembelajaran sejarah dapat disikapi dengan melakukan riset kolaboratif antar dosen di Jurusan Sejarah dengan Dosen lain di Luar Jurusan Sejarah dan memanfatkan hasil kajian tersebut untuk perbaikan kualitas pembelajaran Sejarah.

Kemampuan dosen yang beragam diantisipasi dengan kolaborasi pengembangan perkulaiahan dengan memaksimalkan peran KBK di Jurusan Sejarah. Dosen senior dapat menyusun materi secara konkret dan secara kolaboratif dosen Junior mengemas materi tersebut menjadi beragam media pembelajaran yang menarik dan inovatif. Hal lain yang tidak kalah penting adalah pembangunan karakter mahasiswa, era digital harus diimbangi dengan pembelajaran sejarah yang mengutamakan kemampuan afektif mahasiswa dan psikomorik mahasiswa. Pada setiap proses pembelajaran harus mampu memberikan makna mengapa penting belajar sejarah, Pembelajaran bermakna dapat dilakukan dengan pembelajaran reflektif dari hasil pembelajaran yang telah didapatkan. Pada pelaksanaan pembelajaran sejarah di Jurusan Sejarah masih harus banyak berbenah dalam menyikapi sebuah perubahan, namun perubahan ini bukan suatu keniscayaan namun keharusan untuk menciptakan pembelajaran sejarah yang kritis dan bermakna bagi mahasiswa.

\section{Simpulan}

484 | Seminar Nasional Sejarah ke 4 Jurusan Pendidikan Sejarah Universitas Negeri Padang 
Paradigma baru mengenai pembelajaran sejarah sebagai sebuah pembelajaran yang dapat membangun sebuah pengetahuan yang penting bagi kehidupan manusia harus mulai diterjemahkan secara nyata dalam pembelajaran secara praktis. Zaman telah memasuki babak baru oleh karena itu system dalam pembelajaran sejarah musti diupgrade untuk menyesuaikan dengan kebutuhan zaman tanpa mengesampingkan aspek character values. Hasil survey yang dilakukan di jurusan sejarah UM menunjukkan meski pembelajarn sejarah yang berlangsung selama ini sudah baik dan dosen sudah menggunakan media sebagai penunjang pembelajaran namun semuanya harus diselaraskan dengan kebutuhan. Dalam survey menunjukkan jika kemasan media audio visual menjadi pilihan mayoritas mahasiswa dalam pembelajaran sejarah. Bentuk riil dari medianya berupa video dan film sejarah yang dianggap paling sesuai dengan selera mahasiswa saat ini. Sedangkan problematika utama mahasiswa sejarah zaman sekarang didominasi oleh rendahnya budaya literasi, sesuai dengan problematika bangsa Indonesia yang warganya mempunyai budaya baca yang cukup memprihatinkan.

\section{DAFTAR PUSTAKA}

Alexander König and Daniel Bernsen. 2014. Mobile Learning in History Education. Journal of Educational Media, Memory \& Society, Vol. 6, No. 1 (SPRING 2014), pp. 107-123 Published by: Berghahn Books Stable. https://www.jstor.org/stable/43049676

Andrew C. Butler, Franklin M. Zaromb, Keith B. Lyle, Henry L. Roediger and III. 2009. Using Popular Films to Enhance Classroom Learning: The Good, the Bad, and the Interesting. Psychological Science, Vol. 20, No. 9 (September 2009), pp. 11611168 Published by: Sage Publications, Inc. on behalf of the Association for Psychological Science https://www.jstor.org/stable/40575158

Anirudh Deshpande. 2004. Films as Historical Sources or Alternative History. Economic and Political Weekly. Vol. 39, No. 40 (Oct. 2-8, 2004), pp. 4455-4459. https://www.jstor.org/stable/4415618

Azhar Arsyad. (2006). Media Pembelajaran. Jakarta: Rajawali Pers

Barry, Kevin and Len King. 2004. Beginning Teaching, A Development Text for Effective Teaching. New York : Social Science Press. 
Creswell, J. W. 2014. Research Design: Qualitative, Quantitative and Mixed Methods Approaches, 4 Edition. London: Sage

Daryanto. 2010. Media Pembelajaran. Yogyakarta: Gava Media

Derek McKiernan.1988. Media Education: Learning from History. Teaching History, No. 53 (October 1988), pp. 20-24 Published by: Historical Association. https://www.jstor.org/stable/43256979

Eef Masson Celluloid Teaching Tools: Classroom Films in the Netherlands (1941-1953). Film History, Vol. 19, No. 4, Nontheatrical Film (2007), pp. 392-400.

Fisher, Alec. 2009. Berfikir Kritis. Terjemahan Benyamin Hadinata. Jakarta : Erlangga Hamid, Abd. Rahman. (2014). Pembelajaran Sejarah. Yogyakarta: Ombak.

Husmiati, Ratu. 2010. Kelebihan Dan Kelemahan Media Film Sebagai Media Pembelajaran Sejarah (Survei Pendapat mahasiswa di Jurusan Sejarah FIS-UNJ). Jurnal Sejarah Lontar. Vol.7 No.2 Juli - Desember 2010.

https://news.detik.com/berita/d-4371993/benarkah-minat-baca-orang-indonesia-serendahinidiakses 6 April 2019

https://www.cnnindonesia.com/gaya-hidup/20180326160959-282-285982/minat-bacamasyarakat-indonesia-masih-rendah. diakses 6 April 2019

Janet McCalman. 2000. Learning from History. AQ: Australian Quarterly, Vol. 72, No. 4 (Aug. - Sep., 2000), pp. 15-17, 40 Published by: Australian Institute of Policy and Science. https://www.jstor.org/stable/20637931

Jaime Schultz. 2014. The Truth about Historical Sport Films. Journal of Sport History, Vol. 41, No. 1 (Spring 2014), pp. 29-45.https://www. jstor.org/stable /10.5406 /jsporthistory.41.1.29

John Sundquist. 2010. The Long and the Short of It: The Use of Short Films in the German Classroom. Die Unterrichtspraxis / Teaching German, Vol. 43, No. 2 (Fall 2010), pp. 123-132. Stable URL: https://www.jstor.org/stable/40961802

Kochhar, S. K. 2008. Pembelajaran Sejarah. Jakarta: Grasindo.

Margaret A. Compton .2011. Reviewed Academic Films for the Classroom: A History by Geoff Alexander: Source: The Moving Image: The Journal of the Association of Moving Image Archivists , Vol. 11, No. 2 (Fall 2011), pp. 106-109. https://www.jstor.org/stable/10.5749/movingimage.11.2.0106 
Rusman, dkk. (2012). Pembelajaran Berbasis Teknologi Informasi dan Komunikasi: Mengembangkan Profesionalitas Guru. Jakarta: PT Remaja Grafindo Persada.

Sugiyono. 2010. Metode Penelitian Pendidikan Pendekatan Kuantitatif, kualitatif, dan R\&D. Bandung: Alfabeta

Tilaar, H.A.R. 2000. Paradigma Baru Pendidikan Nasional. Jakarta: Rineka Cipta.

Tim Kurikulum Jurusan Sejarah. 2018. Katalog Jurusan Sejarah. Jurusan Sejarah Fakultas Ilmu Sosial Universitas Negeri Malang.

Tim Kurdev. 2018. Panduan Kurikulum Universitas Negeri Malang Tahun 2018. LP3: Universitas Negeri Malang.

Widja, I Gde. 2018. Pembelajaran Sejarah yang Mencerdaskan, Suatu Alternatif Menghadapi Ancama Kehidupan Berbangsa Berlandaskan Ke-Indonesiaan. Jakarta : Krishna Abadi Publishing

Winkel,W.S. 2009. Psikologi Pengajaran. Yogyakarta: Media Abadi

Y.R. Subakti .2010. Paradigma Pembelajaran Sejarah Berbasis Konstruktivisme. Spps, Vol. 24, No. 1, April 2010. 